\section{Nutritional aspects of the prevention and treatment of osteoporosis}

\author{
Aspectos nutricionais na prevenção e no tratamento da osteoporose
}

Bárbara Santarosa Emo Peters'? Lígia Araújo Martini²
${ }^{1}$ Departamento de Endocrinologia, Faculdade de Medicina,

Universidade Federal de São Paulo (Unifesp/EPM), São Paulo, SP, Brasil ${ }^{2}$ Departamento de Nutrição, Faculdade de Saúde Pública, Universidade de São Paulo (FSP-USP), São Paulo, SP, Brasil calcium retention, reduced age-related bone loss, and reduced fracture risk. Recent evidence indicates that a healthy dietary pattern including dairy products (mainly fat free), fruit and vegetables and adequate amounts of meat, fish and poultry is positively related to bone health. Furthermore, mineral and vitamin supplementation should be closely monitored by health professionals since it could have adverse effects and be insufficient to ensure optimal protection of bone health. Arq Bras Endocrinol Metab. 2010;54(2):179-85

\title{
Keywords
}

Osteoporosis; bone mass; nutrition intake; calcium; vitamin D; protein

\section{SUMÁRIO}

A osteoporose é um problema de saúde global, caracterizada por baixa massa óssea e deterioração da microarquitetura do tecido ósseo, com consequente aumento da fragilidade óssea e suscetibilidade a fraturas. A nutrição desempenha um papel fundamental na redução do risco de osteoporose por seu efeito sobre todos os fatores relacionados à fragilidade óssea, principalmente no desenvolvimento e na manutenção da massa óssea. Uma adequada ingestão de cálcio, vitamina $\mathrm{D}$ e proteína leva à redução da remodelação óssea, à maior retenção de cálcio, à redução da perda óssea relacionada à idade e à redução do risco de fraturas. Evidências recentes indicam que uma alimentação saudável, incluindo a ingestão de produtos lácteos (principalmente os desnatados), frutas e verduras, e uma quantidade adequada de carnes, peixes e aves, está relacionada positivamente com a saúde óssea. Além disso, a suplementação de vitaminas e minerais deve ser monitorada de perto, por profissionais de saúde, uma vez que pode ter efeitos adversos e ser insuficiente para assegurar uma eficaz proteção à saúde óssea. Arq Bras Endocrinol Metab. 2010;54(2):179-85

Osteoporose; massa óssea; ingestão alimentar; cálcio; vitamina D; proteína

Correspondence to: Bárbara Santarosa Emo Peters Av. Eng. Heitor Antonio Eiras Garcia, 400, ap. 53 05588-000 - São Paulo, SP, Brasil bpeters@usp.br

Received on Nov/13/2009 Accepted on Jan/28/2010

\section{INTRODUCTION}

$\mathrm{O}$ steoporosis is defined as a systemic skeletal disease characterized by low bone mass and microarchitectural deterioration of bone tissue, with a consequent increase in bone fragility and susceptibility to fracture (1). Osteoporosis is a global health problem, with the accelerating growth of the older population, it is estima- ted that 52 million people will suffer from osteoporosis or osteopenia by 2010 (1).

After age 50, 1 in 2 women and 1 in 4 men will have an osteoporosis-related fracture (1). Osteoporotic fractures involve a number of factors beyond bone weakness; including falls, slow reflexes, sarcopenia, and inadequate soft tissue padding. Nutrition plays a critical role in reducing the risk of osteoporosis through its 
effect on all of these fragility factors, especially on the development and maintenance of bone mass. Maintaining optimal nutrition and weight bearing activities have been shown to reduce the risk of osteoporosis by as much as $50 \%(2)$.

It is believed that genetic factors determine up to $80 \%$ of peak bone mass with the remainder influenced by environmental factors such as exercise, smoking, medication and nutrition (3). Good nutrition, especially with protein, calcium and vitamin $\mathrm{D}$, is also important for preserving bone mass and strength in adults and the elderly. In addition, attention to nutrition is an important component of a successful rehabilitation program in patients who have had an osteoporotic fracture. In frail elderly patients who have sustained hip fractures this is crucially important, as poor nutritional status can slow down recovery and increase susceptibility to further fractures (4).

\section{CALCIUM}

The mineral calcium plays a major role in bone strength and is of prime nutritional importance in osteoporosis, being essential for bone health throughout life (5).

The primary role of calcium in the body is structural, providing the rigidity necessary for the skeleton and teeth to function mechanically. Bone contains about $99 \%$ of the body's calcium. Calcium in body fluids also exerts critical metabolic functions, binding to proteins, and operating as a signal transmitter and protein activator within cells. Muscle contraction and nerve transmission are two of the many body functions that rely on calcium for activation. Additionally, calcium is also involved in blood clotting (6).

Calcium is required for normal growth and development of the skeleton (1). Adequate calcium intake is critical for achieving optimal peak bone mass and modifies the rate of bone loss associated with aging (1). Over the past decade, convincing evidence has emerged with respect to effects of dietary calcium on bone health in all age groups. Unfortunately, there is a significant proportion of some population groups failing to achieve the recommended calcium intakes in a number of Western countries (7).

After menopause, changes in sex hormone levels and nutrition are associated with an increase in bone remodeling, leading thereby to an increase in bone fragility. Epidemiological studies report that a lifetime of high calcium intakes can reduce fracture risk by as much as $60 \%(8)$. In adults, obligatory calcium losses have to be offset by sufficient calcium intakes and efficacious intestinal absorption. Otherwise, bone is used as a source of calcium to maintain homeostasis in extracellular calcium concentration (9).

In a review of 52 calcium intervention studies, 50 showed that increasing calcium intakes resulted in reduced bone remodeling, better calcium retention, reduced agerelated bone loss, and reduced fracture risk. The review also reported that out of 86 observational studies, 64 reported relationships in favor of increased calcium intakes, with reduced fracture risk, bone loss or improved bone mass. While most of the investigator-controlled studies used calcium supplements, six used dairy sources of calcium; all were positive. Most of the observational studies were also based on dairy calcium, and approximately $75 \%$ supported the conclusion that increased calcium from dairy foods is protective of the skeleton (10).

The positive effects of calcium supplementation have essentially been ascribed to a reduction in bone remodeling. However, calcium supplements may be associated with mild gastrointestinal disturbances such as constipation, flatulence, nausea, gastric pain, and diarrhea. Calcium may also interfere with the intestinal absorption of iron and zinc (9). Additionaly, it has been reported that calcium supplementation in healthy postmenopausal women was associated with an increased risk of cardiovascular events in women with more than 80 years of age and a previous cardiovascular event (11). Postmenopausal women received $1,000 \mathrm{mg} /$ day of calcium supplementation plus an intake of approximately $860 \mathrm{mg} /$ day of calcium from the diet. However, such amount is considered too high to be applied in clinical practice. These observed effects indicate that the use of calcium supplements should be considered only when the intake of this nutrient is below the recommended level for each stage in life.

Recommended daily calcium intakes for populations vary between countries, often as a result of differing use and interpretation of the available scientific data (12). The recommendations for calcium intake in $\mathrm{mg} /$ day from several countries are shown in table 1 .

Milk and other dairy foods are the most readily available sources of calcium in the diet. Dairy foods have the additional advantage of being good sources of protein and other micronutrients (besides calcium) that are important for bone and general health. Other good food sources of calcium include certain green vegetables (e.g. broccoli, curly kale, bok choy); whole canned fish with soft, edible bones such as sardines or 
pilchards; nuts; and tofu set with calcium (4). Some examples of the approximate calcium levels in foods are shown in table 2.

Table 1. Recommendation for calcium intake in $\mathrm{mg} /$ day from several countries

\begin{tabular}{lcccccc}
\hline \multirow{2}{*}{ Country/Organization } & \multicolumn{2}{c}{ Adults } & & \multicolumn{2}{c}{ Elderly } \\
\cline { 2 - 3 } \cline { 5 - 6 } & Men & Women & & Men & Women \\
\hline Australia & 800 & 800 & & 800 & 1,000 \\
European Community & 700 & 700 & & 700 & 700 \\
FA0/WH0 & 1,000 & 100 & & 1,300 & 1,300 \\
Mexic0 & 800 & 800 & & 800 & 800 \\
United Kingdom & 700 & 700 & & 700 & 700 \\
Food Nutrition Board & 1,000 & 1,000 & & 1,200 & 1,200 \\
Japan & 600 & 600 & & 600 & 600 \\
\hline
\end{tabular}

FAO/WHO: Food and Agriculture Organization of the United Nations/World Health Organization. Adapted from Looker (12).

Table 2. Approximate calcium levels in foods

\begin{tabular}{|c|c|c|}
\hline Food & Serving size & Calcium (mg) \\
\hline Milk, whole & $236 \mathrm{~mL} / 8 \mathrm{fl} \mathrm{oz}$ & 278 \\
\hline Milk, semi-skimmed & $236 \mathrm{~mL} / 8 \mathrm{fl} \mathrm{oz}$ & 283 \\
\hline Milk, skimmed & $236 \mathrm{~mL} / 8 \mathrm{fl} \mathrm{oz}$ & 288 \\
\hline Yoghurt, low fat, plain & $150 \mathrm{~g} / 5$ oz & 243 \\
\hline Yoghurt, low fat, fruit & $150 \mathrm{~g} / 5 \mathrm{oz}$ & 210 \\
\hline Cheese, cheddar type & 40 g/medium-size chunk & 296 \\
\hline Cheese, cottage & $112 \mathrm{~g} / 4 \mathrm{oz}$ & 142 \\
\hline Cheese, mozzarella & $28 \mathrm{~g} / 10 \mathrm{z}$ & 101 \\
\hline Cheese, Camembert & 40 g/average portion & 94 \\
\hline Ice cream, dairy, vanilla & 75 g/average serving & 75 \\
\hline Tofu, soya bean, steamed & $100 \mathrm{~g} / 3.5 \mathrm{oz}$ & 510 \\
\hline Soya drink & $236 \mathrm{~mL} / 8 \mathrm{fl} 0 \mathrm{z}$ & 31 \\
\hline Soya drink, calcium-enriched & $236 \mathrm{~mL} / 8 \mathrm{fl} \mathrm{oz}$ & 210 \\
\hline Broccoli, cooked & $112 \mathrm{~g} / 4 \mathrm{oz}$ & 45 \\
\hline Curley kale, cooked & $112 \mathrm{~g} / 4 \mathrm{oz}$ & 168 \\
\hline Apricots, raw, stone removed & $160 \mathrm{~g} / 4$ fruit & 117 \\
\hline Orange, peeled & $160 \mathrm{~g} / 1$ fruit & 75 \\
\hline Figs, ready to eat & $220 \mathrm{~g} / 4$ fruit & 506 \\
\hline Almonds & $26 \mathrm{~g} / 12$ whole & 62 \\
\hline Sardines, canned in oil & $100 \mathrm{~g} / 4$ sardines & 500 \\
\hline Whitebait, fried & 80g/average portion & 688 \\
\hline Bread, white, sliced & $30 \mathrm{~g} / 1$ medium slice & 53 \\
\hline Bread, wholemeal, sliced & $30 \mathrm{~g} / 1$ medium slice & 32 \\
\hline Pasta, plain, cooked & 230 g/medium portion & 85 \\
\hline Rice, white, basmati, boiled & $180 \mathrm{~g} /$ medium portion & 32 \\
\hline
\end{tabular}

Adapted from International Osteoporosis Foundation, 2006 (4).
Although some other plant foods also contain appreciable amounts of calcium, some contain substances that bind to the calcium and prevent it from being absorbed, e.g. compounds called oxalates in spinach and rhubarb, and phytates in dried beans, cereal husks and seeds (13). However, oxalates and phytates only bind the calcium in the foods they are in - they do not interfere with calcium absorption from other foods or drinks. Calcium-fortified foods and drinks, including breads, cereals, orange juice and soy beverages are also available in some countries, as are various commercial brands of mineral waters which can contain significant amounts of calcium. Soy beverages are sometimes called 'soy milk', but it is important to look for the ones that are fortified with calcium, because soy drinks do not naturally contain calcium (4).

\section{VITAMIN D}

Vitamin D is also essential for the development and maintenance of bone, both for its role in assisting calcium absorption from the diet, and for ensuring the proper renewal and mineralization of bone tissue (4).

Vitamin D deficiency is characterized by inadequate mineralization, or demineralization, of the skeleton. In adults, severe vitamin $\mathrm{D}$ deficiency leads to a mineralization defect in the skeleton causing osteomalacia (4). In addition, the secondary hyperparathyroidism associated with low vitamin $\mathrm{D}$ status enhances mobilization of calcium from the skeleton (4). There is a considerable body of evidence that vitamin $\mathrm{D}$ deficiency is an important contributor to osteoporosis through less efficient intestinal absorption of calcium, increased bone loss, muscle weakness, and a weakened bone microstructure (14).

Increasing vitamin D intake can significantly reduce the risk of osteoporosis and bone fracture in older people. A recent study of Caucasian postmenopausal women from the National Osteoporosis Risk Assessment study (NORA) reported that lifetime current vitamin $\mathrm{D}$ intakes were also associated with reduced risk for osteoporosis over three years, OR 0.73 (95\% CI: 0.66-0.81) (15). In a meta-analysis realized for Bischoff-Ferrari and cols. in 2005 (16), the antifracture efficacy of oral vitamin D supplementation in older persons was evaluated. The author showed that vitamin $\mathrm{D}$ intakes of 700-800 IU/day reduced the relative risk of hip fracture by $26 \%$ and any nonvertebral fracture by $23 \%$ compared with calcium or placebo. No significant 
benefit was observed in double-blind randomized control trials with intakes of $400 \mathrm{IU}$ vitamin $\mathrm{D} /$ day.

Scientific evidence suggests that on a global level, vitamin $\mathrm{D}$ insufficiency is widespread, even in very sunny regions such as the Middle East, Latin American and Asian countries, and in Australia. This is clearly demonstrated in a cross-sectional observational international study in 1,285 community-dwelling, postmenopausal women with osteoporosis, in 18 countries. The prevalence of vitamin D inadequacy (defined as $<30 \mathrm{ng} / \mathrm{mL}$ ) was over $50 \%$ in all five world regions, and was highest in the Middle East (81\%) and Asia (63\%) (17). In Brazil, a cross-sectional study evaluated serum levels of 25-hydroxyvitamin $\mathrm{D}[25(\mathrm{OH}) \mathrm{D}]$ in the elderly living in the city of São Paulo, the authors observed that $71.2 \%$ of the inpatient group and $43.8 \%$ of the outpatient group had 25OHD levels below the minimum recommended $(50 \mathrm{nmol} / \mathrm{L})(18)$. Vitamin D insufficiency was also observed in $24 \%$ of women with osteoporosis (19).

However, optimal serum concentrations of $25(\mathrm{OH})$ $\mathrm{D}$ have not been defined. A recent review summarized evidence from studies that evaluated thresholds for serum $25(\mathrm{OH}) \mathrm{D}$ concentrations in relation to bone mineral density (BMD), lower-extremity function, dental health, and risk of falls, fractures, and colorectal cancer. It was observed that for all endpoints, the most advantageous serum concentrations of $25(\mathrm{OH}) \mathrm{D}$ begin at $75 \mathrm{nmol} / \mathrm{L}$, and the best are between 90 and $100 \mathrm{nmol} / \mathrm{L}(20)$.

A large part of the population is currently below the $75 \mathrm{nmol} / \mathrm{L}$ threshold and could certainly benefit from appropriate vitamin D supplementation. For most patients with vitamin $\mathrm{D}$ deficiency, correcting vitamin $\mathrm{D}$ serum levels as quickly as possible is the goal. Typically, patients receiving 50,000 IU of vitamin D once a week for 8 weeks will correct vitamin D deficiency (21). Aloia and cols. in 2008 (22), suggest a dose of 3800 IU/ day of vitamin $\mathrm{D}$ for individuals with serum $25(\mathrm{OH})$ D levels above $55 \mathrm{nmol} / \mathrm{L}$ and a dose of $5000 \mathrm{IU} /$ day for those below that threshold, with the purpose to attain a serum $25(\mathrm{OH}) \mathrm{D}$ concentration $>75 \mathrm{nmol} / \mathrm{L}$. Mosekilde suggests that in adults, a minimum dietary intake of 700-1000 IU/day is necessary to achieve levels between 75 and $100 \mathrm{nmol} / \mathrm{L}(23)$.

A recent paper by Cashman and cols. (24), recommends that the vitamin D intake necessary to maintain the vast majority $(97.5 \%)$ of elderly aged $\geq 64$ years of age during winter with serum $25(\mathrm{OH}) \mathrm{D}$ levels $>80$ $\mathrm{nmol} / \mathrm{L}$ should be of 1,548 IU/day. Estimated dietary vitamin $\mathrm{D}$ requirements at selected percentile in elderly aged $\geq 64$ years of age to maintain serum $25(\mathrm{OH}) \mathrm{D}$ concentrations above selected biochemical cutoffs during winter are shown in table 3 .

Table 3. Estimated dietary vitamin $D$ requirements at selected percentile in adults aged $\geq 64$ years to maintain serum $25(\mathrm{OH}) \mathrm{D}$ concentrations above selected biochemical cutoffs during winter

\begin{tabular}{lcccc}
\hline & \multicolumn{4}{c}{ Percentile } \\
\cline { 2 - 5 } Serum 25(OH)D cutoff & 50th & 90th & 95th & 97,5th \\
\cline { 2 - 5 } & \multicolumn{4}{c}{ IU/day } \\
\hline$>25 \mathrm{nmol} / \mathrm{L}$ & - & 104 & 232 & 344 \\
$>37.5 \mathrm{nmol} / \mathrm{L}$ & - & 448 & 576 & 688 \\
$>50 \mathrm{nmol} / \mathrm{L}$ & 284 & 736 & 872 & 988 \\
$>80 \mathrm{nmol} / \mathrm{L}$ & 860 & 1,328 & 1,464 & 1,548 \\
\hline
\end{tabular}

IU: International Unit. Adapted from Cashman and cols. (24).

Very little vitamin D is naturally present in our food, which includes oily (or fatty) fish such as salmon, tuna, sardines and mackerel, egg yolk and liver. In some countries, fortified foods specifically labeled as such, including milk and other dairy foods, margarine, and breakfast cereals, are viable options (4). Some examples of the approximate vitamin D levels in foods are shown in table 4 .

Table 4. Approximate vitamin D levels in foods

\begin{tabular}{lccc}
\hline Food & $\begin{array}{c}\text { Mg per } \\
\text { serving }\end{array}$ & $\begin{array}{c}\text { IU per } \\
\text { serving }\end{array}$ & $\begin{array}{c}\text { \% RNI } \\
\text { (for ages } \\
\text { 51-65 years) }\end{array}$ \\
\hline Cod liver oil** 1 tbsp & 23.1 & 924 & 231 \\
Salmon, grilled, $100 \mathrm{~g}$ & 7.1 & 284 & 71 \\
Mackerel, grilled, $100 \mathrm{~g}$ & 8.8 & 352 & 88 \\
Tuna, canned in brine, $100 \mathrm{~g}$ & 3.6 & 144 & 36 \\
Sardines, canned in brine, $100 \mathrm{~g}$ & 4.6 & 184 & 46 \\
Egg, hen, average size, $50 \mathrm{~g}$ & 0.9 & 3 & 9 \\
Liver, lamb, fried, $100 \mathrm{~g}$ & 0.9 & 36 & 9 \\
Margarine, fortified, $20 \mathrm{~g}$ & 1.6 & 62 & 16 \\
Bran Flakes***, average serving, $30 \mathrm{~g}$ & 1.3 & 52 & 13 \\
\hline
\end{tabular}

* The RNI (recommended nutrient intake) for adults, ages 51-65 years. The RNI is defined by the FAO/WHO as "the daily intake which meets the nutrient requirements of almost all (97.5\%) apparently healthy individuals in an age- and sex-specific population group". Daily intake corresponds to the average over a period of time. ${ }^{* \star}$ Fish liver oils, such as cod liver oil and halibut liver oil, also contain appreciable amounts of vitamin $\mathrm{A}$, which can be toxic if consumed in excess. ${ }^{* *}$ Bran Flakes are given as an example of a vitamin D-fortified breakfast cereal.

Adapted from International Osteoporosis Foundation, 2006 (4).

\section{PROTEIN}

Protein should be the central part of a complete diet for adults. While physical growth occurs only for a brief period of life the need to repair and remodel muscle and bone continues throughout life. Maintaining the 
health of muscle and bone is an essential part of the aging process and critical to maintain mobility, health and the active tissues of our body (25).

Protein is also a key constituent of bone tissue and therefore an adequate dietary supply is essential (4). The majority of the observational studies support a positive association between protein intake and bone health. There are several epidemiological studies, both cross-sectional and longitudinal that have reported an association between dietary protein and bone (26-28). These studies reveal that individuals who consume the most dietary protein have the highest BMD. In addition, prospective studies have observed that individuals with the highest protein intake have the slowest rate of bone loss $(26,29)$.

One of the mechanisms by which dietary protein may improve bone mass can be explained by the fact that increasing dietary protein is also known to increase circulating levels of insulin-like growth factor 1 (IGF-1), and conversely, a low-protein diet decreases IGF-1 (30). IGF-l is a key mediator of bone growth but also has a role in the skeletal response to anabolic Parathyroid Hormone (PTH) therapy (31). Increasing dietary protein from 0.85 to $1.55 \mathrm{~g} / \mathrm{kg}$ per day resulted in lower markers of bone resorption and higher circulating levels of IGF-1 in healthy older men and women (32).

Dietary proteins would induce systemic acidosis and thereby would promote bone mineral dissolution (33). Increasing protein intake may increase acid production and renal acid excretion as a consequence of protons released during the oxidation of sulphur-containing aminoacids such as methionine, cysteine and cystine (9). An acidic environment affects bone in several ways, and an acidogenic (high-protein) diet induces calciuria (34).

The administration of alkaline salts of potassium can be used to reverse the negative effects of acidogenic diets. A randomized, placebo-controlled, double-blind study showed that in older adults, potassium bicarbonate attenuates the protein-induced rise in urinary nitrogen excretion and may promote calcium absorption in subjects with both low and high protein diet intake (35). In another double-blind, controlled trial study, it was observed that potassium bicarbonate had a favorable effect on bone resorption and calcium excretion, suggesting that increasing the alkali content of the diet may attenuate bone loss in healthy older adults (36).

On the other hand, it has been hypothesized that increasing dietary protein in humans results in higher urinary calcium. In fact, previous calcium balance stud- ies did not show an improvement in calcium absorption (even with high protein intake), the increase in urinary calcium was assumed to be of bone origin, which leads to the hypothesis that high protein diets are detrimental to the skeleton (37). However, a recent study demonstrated that the increase in urinary calcium excretion is due to improved intestinal calcium absorption, and high protein diets do not result in negative skeletal calcium balance $(37,38)$.

However, as described above, higher protein intakes are associated with improvements in BMD and skeletal metabolism in the elderly. Furthermore, many proteinrich foods such as meat and dairy foods are also rich in phosphorus and potassium, both of which have an opposing effect in that they tend to prevent urinary calcium loss (39). Finally, some aminoacids promote calcium absorption which would also offset urinary losses, and as long as calcium intake is adequate, higher protein intakes have been shown to improve bone density (37).

Mounting evidence suggests that the Recommended Dietary Allowance (RDA) for protein of $0.8 \mathrm{~g} / \mathrm{kg}$ per day is not optimal for bone health in elderly people. Reassessments of the nitrogen balance studies show that a protein intake of 1.0 to $1.3 \mathrm{~g} / \mathrm{kg}$ per day is needed to offset the typically lower energy intake and impaired insulin response in elderly individuals (40). Moderate protein diets of 1.0 to $1.5 \mathrm{~g} / \mathrm{kg}$ per day are shown to be associated with normal calcium homeostasis without altering bone metabolism (37). These data seem to indicate that doubling the RDA from $0.8 \mathrm{~g} / \mathrm{kg}$ per day to 1.5 to $1.6 \mathrm{~g} / \mathrm{kg}$ per day may result in better muscle and bone health in elderly individuals. Although this level is approximately twice the current $\mathrm{RDA}$, it is still within the acceptable range of intake ( $10 \%-35 \%$ of total calories) (41). Based on these data, a recommendation of 1.0 to $1.2 \mathrm{~g} / \mathrm{kg}$ per day of proteins (or approximately $13 \%-16 \%$ of total calories) would maintain normal calcium metabolism and nitrogen balance without affecting renal function.

In summary, the majority of scientific evidence - including that from clinical trials - supports beneficial effects of protein intake on bone health, and highlights the risks associated with protein insufficiency and malnutrition.

\section{MAGNESIUM AND PHOSPHORUS}

Approximately $60 \%$ of the magnesium $(\mathrm{Mg})$ in the body is in bone. $\mathrm{Mg}$ influences mineral metabolism indirectly through its role in ATP metabolism and as a cofactor 
for over 300 proteins, the calciotropic hormones and $1,25(\mathrm{OH})_{2} \mathrm{D}$. Mg also influences bone health by direct effects on bone quality, decreasing hydroxyapatite crystal size, thereby preventing the larger, more perfect mineral crystals that cold lead to brittle bone (42). Severe experimental magnesium deficiency results in abnormal bone structure and function, but this level of depletion is rarely observed in generally well nourished human populations (43). Magnesium is fairly widespread in the food chain; particularly good sources include green vegetables, legumes, nuts, seeds, unrefined grains, and fish (4). Recent studies have found a positive association between fruit and vegetable consumption and bone health $(44,45)$. However, there are no studies to date which demonstrate that magnesium supplementation is useful either in preventing bone loss or reducing fracture risk (4). The majority of the phosphorus in the body is found as phosphate $\left(\mathrm{PO}_{4}\right)$. Approximately $85 \%$ of the body's phosphorus is found in bone. Phosphorus is found in most foods because it is a critical component of all living organisms. Dairy products, meat, and fish are particularly rich sources of phosphorus. Phosphorus is also a component of many polyphosphate food additives and is present in most soft drinks as phosphoric acid (42).

Some investigators are concerned about the increasing amounts of phosphates in the diet. Because phosphorus is not as tightly regulated by the body as calcium, serum phosphate levels can rise slightly with a high phosphorus diet, especially after meals. High phosphate levels in the blood reduce the formation of the active form of vitamin D (calcitriol) in the kidneys, reduce blood calcium, and lead to increased PTH release by the parathyroid glands. However, high serum phosphorus levels also lead to decreased urinary calcium excretion (46). If sustained, elevated PTH levels could have an adverse effect on bone mineral content, but this effect has only been observed in humans on diets that were high in phosphorus and low in calcium. Moreover, similarly elevated PTH levels have been reported in diets that were low in calcium without being high in phosphorus (47). A controlled trial in young women found no adverse effects of a phosphorus-rich diet $(3,000 \mathrm{mg} /$ day $)$ on bone-related hormones and biochemical markers of bone resorption when dietary calcium intakes were maintained at almost $2,000 \mathrm{mg} /$ day (48). At present, there is no convincing evidence that the dietary phosphorus levels experienced in the U.S. adversely affect bone mineral density. However, the substitution of phosphate-containing soft drinks and snack foods for milk and other calcium rich foods does represent a serious risk to bone health.

\section{CONCLUSIONS}

Bone health rests on a combination of several factors including on an adequate dietary pattern. Recent evidence indicates that a healthy diet with adequate amounts of protein, calcium, vitamin $\mathrm{D}$, and nutrients that promote a more alkaline ambience such as potassium, would favor bone metabolism. In this regard optimal protection of bone requires a diet rich in dairy products (mainly fat free), fruit and vegetables and adequate amounts of meat, fish and poultry. Furthermore, mineral and vitamin supplementation should be closely monitored by health professionals since it could have adverse effects and be insufficient to ensure optimal protection of bone health.

Disclosure: no potential conflict of interest relevant to this article was reported.

\section{REFERENCES}

1. National Osteoporosis Foundation. 2008. Avaliable from: www. nof.org/osteoporosis/diseasefacts.html.

2. Dawson-Hughes B, Harris SS, Krall EA, Dallal GE. Effect of calcium and vitamin $D$ supplementation on bone density in men and women 65 years of age or older. N Engl J Med. 1997;337:670-6.

3. Ilich JZ, Kerstetter JE. Nutrition in bone health revisited: a story beyond calcium. J Am Coll Nutr. 2000;19:715-37.

4. International Osteoporosis Foundation. Invest in your bones. Bone Appétit - The role of food and nutrition in building and maintaining strong bones. 2006. Avaliable from: http://www.iofbonehealth.org/publications/bone-appetit.html.

5. North American Menopause Society. The role of calcium in periand postmenopausal women: 2006 position statement of the North American Menopause Society. Menopause. 2006;13:862-77.

6. Heaney RP. Dairy and bone health. J Am Coll Nutr. 2009;28( Suppl 1):82S-90S.

7. Cashman KD. Calcium intake, calcium bioavailability and bone health. Br J Nutr. 2002;87:S169-77.

8. Heaney RP. Calcium in the prevention and treatment of osteoporosis. J Intern Med. 1992;231:169-80.

9. Rizzoli R. Nutrition its role in bone health. Best Pract Res Clin Endocrinol Metab. 2008;22(5):813-29.

10. Heaney RP. Calcium, dairy products and osteoporosis. J Am Coll Nutr. 2000;19(2 Suppl):83S-99S.

11. Bolland MJ, Barber PA, Doughty RN, Mason B, Horne A, Ames $R$, et al. Vascular events in healthy older women receiving calcium supplementation: randomised controlled trial. BMJ. 2008;336:262-6.

12. Looker AC. Dietary calcium: recommendation and intakes around the world. In: Weaver CM, Heaney RP, editors. Calcium in the Human Health, 1.ed. Totowa, New Jersey: Humana Press; 2006. p. 105-27. 
13. Weaver CM, Proulx WR, Heaney R. Choices for achieving adequate calcium with a vegetarian diet. Am J Clin Nutr. 1999;70(Suppl):543S-48S.

14. Department of Health. Nutrition and bone health with reference to calcium and vitamin D. Dietary reference values for food energy and nutrients for the United Kingdom. Report in Health and Social Subjects no. 49. London: HM Stationery Office; 1998.

15. Nieves JW, Barrett-Connor E, Siris ES, Zion M, Barlas S, Chen YT. Calcium and vitamin D intake influence bone mass, but not short-term fracture risk, in Caucasian postmenopausal women from the National Osteoporosis Risk Assessment (NORA) study. Osteoporos Int. 2008;19:673-9.

16. Bischoff-Ferrari HA, Willett WC, Wong JB, Giovannucci E, Dietrich T, Dawson-Hughes B. Fracture prevention with vitamin D supplementation: a meta-analysis of randomized controlled trials. JAMA. 2005;293:2257-64.

17. Lim SK, Poor G, Benhamou C-L, et al. Vitamin D inadequacy is a global problem in osteoporotic women. J Clin Densitom. 2005;8(2):239. (Abstract).

18. Saraiva GL, Cendoroglo MS, Ramos LR, Araújo LM, Vieira JG, Maeda SS, et al. Prevalência da deficiência, insuficiência de vitamina $\mathrm{D}$ e hiperparatiroidismo secundário em idosos institucionalizados e moradores na comunidade da cidade de São Paulo, Brasil. Arq Bras Endocrinol Metab. 2007;51(3):437-42.

19. Genaro PS, Pereira GAP, Pinheiro MM, Szjenfeld VL, Martini LA. Relationship between nutrient intake and vitamin D in osteoporotic women. Int J Vitamin Nutr Res. 2007;77(6):376-81.

20. Bischoff-Ferrari HA, Giovannucci E, Willett WC, Dietrich T, Dawson-Hughes B. Estimation of optimal serum concentrations of 25-hydroxyvitamin D for multiple health outcomes. Am J Clin Nutr. 2006;84(1):18-28.

21. Malabanan $A$, Veronikis IE, Holick MF. Redefining vitamin $D$ insufficiency. Lancet. 1998;351(9105):805-6.

22. Aloia JF, Patel M, Dimaano R, Li-Ng M, Talwar SA, Mikhail M, et al. Vitamin $D$ intake to attain a desired serum 25-hydroxyvitamin $D$ concentration. Am J Clin Nutr. 2008;87(6):1952-8.

23. Mosekilde L. Vitamin D requirement and setting recommendation levels: long-term perspectives. Nutr Rev. 2008;66(10 Suppl 2):S170-7.

24. Cashman KD, Wallace JM, Horigan G, Hill TR, Barnes MS, Lucey $A J$, et al. Estimation of the dietary requirement for vitamin $D$ in free-living adults $\geq 64$ y of age. Am J Clin Nutr. 2009;89(5):1366-74.

25. Layman DK. Dietary Guidelines should reflect new understandings about adult protein needs. Nutr Metabol. 2009;6:12.

26. Promislow JH, Goodman-Gruen D, Slymen DJ, Barrett-Connor E. Protein consumption and bone mineral density in the elderly: The Rancho Bernardo Study. Am J Epidemiol. 2002;155:636-44.

27. Kerstetter JE, Looker AC, Insogna KL. Low dietary protein and low bone density. CalcifTissue Int. 2000;66:313.

28. Rapuri PB, Gallagher JC, Haynatzka V. Protein intake: effects on bone mineral density and the rate of bone loss in elderly women. Am J Clin Nutr. 2003;77:1517-25.

29. Hannan MT,Tucker KL, Dawson-Hughes B, Cupples LA, Felson DT, Kiel DP. Effect of dietary protein on bone loss in elderly men and women:The Framingham Osteoporosis Study. J Bone Miner Res. 2000;15:2504-12.

30. Bonjour JP, Schurch MA, Chevalley T, Ammann P, Rizzoli R. Protein intake, IGF-1 and osteoporosis. Osteoporos Int. 1997;7(Suppl 3):S36-42.

31. Bikle DD, SakataT, Leary C, Elalieh H, Ginzinger D, Rosen CJ, et al. Insulin-like growth factor $I$ is required for the anabolic actions of parathyroid hormone on mouse bone. J Bone Miner Res. 2002;17:1570-8.
32. Dawson-Hughes B, Harris SS, Rasmussen H, Song L, Dallal GE. Effect of dietary protein supplements on calcium excretion in healthy older men and women. J Clin Endocrinol Metab. 2004;89:1169-73.

33. Bonjour JP. Dietary protein: an essential nutrient for bone health. J Am Coll Nutr. 2005;24(6 Suppl):526S-36S.

34. Kerstetter JE, O'Brien KO, Insogna KL. Low protein intake: the impact on calcium and bone homeostasis in humans. J Nutr. 2003;133:855S-61S.

35. Ceglia L, Harris SS, Abrams SA, Rasmussen HM, Dallal GE, Dawson-Hughes $B$. Potassium bicarbonate attenuates the urinary nitrogen excretion that accompanies an increase in dietary protein and may promote calcium absorption. J Clin Endocrinol Metab. 2009;94(2):645-53.

36. Dawson-Hughes B, Harris SS, Palermo NJ, Castaneda-Sceppa C, Rasmussen HM, Dallal GE. Treatment with potassium bicarbonate lowers calcium excretion and bone resorption in older men and women. J Clin Endocrinol Metab. 2009;94(1):96-102.

37. Kerstetter JE, O'Brien KO, Caseria DM, Wall DE, Insogna KL. The impact of dietary protein on calcium absorption and kinetic measures of bone turnover in women. $\mathrm{J}$ Clin Endocrinol Metab. 2005;90:26-31.

38. Hunt JR, Johnson LK, Roughead ZK. Dietary protein and calcium interact to influence calcium retention: a controlled feeding study. Am J Clin Nutr. 2009;89(5):1357-65.

39. Heaney RP. Nutrients, interactions, and foods: the importance of source. In: Burckhardt P, Dawson-Hughes B, Heaney RP, eds. Nutritional Aspects of Osteoporosis, 2.ed. Burlington, MA: Elsevier Academic Press; 2004.

40. Campbell WW, TrappeTA, Wolfe RR, Evans WJ.The recommended dietary allowance for protein may not be adequate for older people to maintain skeletal muscle. J Gerontol A Biol Sci Med Sci. 2001;56A:M373-80.

41. Gaffney-Stomberg $E$, Insogna $K L$, Rodriguez NR, Kerstetter JE. Increasing dietary protein requirements in elderly people for optimal muscle and bone health. J Am Geriatr Soc. 2009;57(6):1073-9.

42. Bonjour JP, Guéguen L, Palacios C, Shearer MJ, Weaver CM. Minerals and vitamins in bone health: the potential value of dietary enhancement. Br J Nutr. 2009;101(11):1581-96.

43. Schwarz R. Magnesium metabolism. In: Simmons DJ. Nutrition and bone development. NewYork: Oxford University Press; 1990. p. $148-63$.

44. Macdonald HM, New SA, Fraser WD, Campbell MK, Reid DM. Low dietary potassium intakes and high dietary estimates of net endogenous acid production are associated with low bone mineral density in premenopausal women and increased markers of bone resorption in postmenopausal women. Am J Clin Nutr. 2005;81(4):923-33.

45. New SA. Intake of fruit and vegetables: implications for bone health. Proc Nutr Soc. 2003;62(4):889-99.

46. Food and Nutrition Board, Institute of Medicine. Phosphorus. Dietary Reference Intakes: Calcium, Phosphorus, Magnesium, Vitamin D, and Fluoride. Washington D.C.: National Academy Press; 1997. p. 146-89.

47. Weaver CM, Heaney RP. Calcium. In: Shils M, Olson JA, Shike M, Ross AC, eds. Nutrition in health and disease. 9th ed. Baltimore: Williams \& Wilkins; 1999. p. 141-55.

48. Grimm M, Muller A, Hein G, Funfstuck R, Jahreis G. High phosphorus intake only slightly affects serum minerals, urinary pyridinium crosslinks and renal function in young women. Eur J Clin Nutr. 2001;55(3):153-61. 